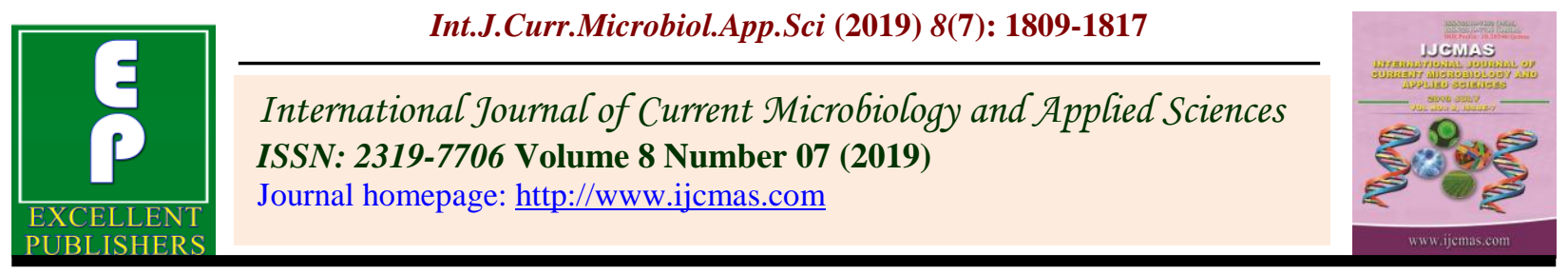

Original Research Article

https://doi.org/10.20546/ijcmas.2019.807.215

\title{
An Extensive Work on Roving Survey of Panama wilt Disease (Fusarium oxysporum f. sp. cubense) of Banana in Bihar
}

\author{
D.N. Shukla* and S.K. Singh \\ Department of Plant Pathology, Dr. Rajendra Prasad Central Agricultural University, \\ Pusa, Samastipur, Bihar, India \\ *Corresponding author
}

\begin{tabular}{|l|}
\hline Key w ord s \\
$\begin{array}{l}\text { Fusarium, Panama } \\
\text { wilt, Strain }\end{array}$ \\
\hline Article Info \\
\hline $\begin{array}{l}\text { Accepted: } \\
\text { 15 June } 2019 \\
\text { Available Online: } \\
\text { 10 July } 2019\end{array}$ \\
\hline
\end{tabular}

\section{A B S T R A C T}

This work was conducted in banana producing area of Bihar during 2016-17 to 2018-19. In Bihar, banana production mainly categorised into two zone viz. Vaishali belt and Koshi belt. Vaishali belt mainly comprise tall group of banana cultivar whereas Kosi belt rich with dwarf Cavendish group of banana cultivars and this dwarf Cavendish group of cultivars were resistant against Panama wilt till 2015.But due to introduction of new race i.e. race 4 strain $\mathrm{B}_{2}$ of Fusarium oxysporum f. sp. cubense. Now it become susceptible and produce peculiar symptom of Panama wilt disease. In this way aroving survey was made on the external symptom expression and find out percent wilt index (0-5). Maximum percent wilt index was recorded in cultivar Malbhog (AAB) from 36-40\% to 3034\% during 2016-17 to 2018-19 in Samastipur districts and minimum percent wilt index was found in cultivars Alpan (AAB) from 21-23\% to 16-17\% during 201617 to 2018-19 in Darbhanga district of Vaishali belt. In Koshi belt, maximum percent wilt index was recorded in cultivar Grand Naine (AAA) from 23-25\% to 28-34\% during 2016-17 to 2018-19 of Bhagalpur district and minimum per cent wilt index was found in cultivar Basrai (AAA) from 9-11\% to $14-18 \%$ during 2016-17 to 2018-19 of Kishanganj district.

\section{Introduction}

Banana and plantains are considered as one of the major staple fruit crops for millions of people in the various developing countries of tropical and sub-tropical region. Banana cultivation is as old as Indian civilization and recognized to be one of the earliest fruit crops cultivated by mankind from prehistoric times in India with great socio-economic importance. Banana is being used as different ways like food, fibre, medicinal, cultural and industrial purposes. This plant also gives good returns to small holders as well as banana growers so it is referred to as "Kalpatharu"- a plant of virtues. The banana plant is one of the oldest fruits known to people since long times and have been named botanically as Musa paradisiaca, it was also referred to be as the Apple of Paradise. It is regularly brought up in 
the Great Indian epics, Ramayana (2020 BC) and Arthashastra of Kautilya (300-400 BC).

The origin seems to be India and afterwards this crop was extents to many countries including Ceylon, Columbia, Costa Rica, Ecuador, Honduras, India, Jamaica, Mexico, Panama and several other Eastern countries. The centre of origin of bananas is treated to be South East Asia, mostly from Assam to the western Pacific (Horry et al., 1997). In India bananas are so prevailing and accepted among the people, which are liked both by poor and rich alike. Considering about the nutritive value and fruit values of banana, it could be coincided as poor man's apple and it is available around the year unlike seasonal opportunity of other fruits. Eighty-seven percent of the bananas cultivated in the tropical and subtropical areas are used for domestic consumption, whereas only $13 \%$ of the total produce is exported even though banana is a significant fruit crop in the international markets fascinating US\$ 4.7 billion each year (Tripathi et al., 2011).

Banana is also profitable for the patients having high blood pressure and heart diseases, as it contains little amount of sodium, very low fat and no cholesterol. It is rich in vitamins A, B and C (Wall, 2006) and minerals like potassium and calcium. Carbohydrate, protein and moisture content of banana fruits mainly depend upon the variety, genotype and climatic conditions (Mohapatra et al., 2010). Banana is an important fruit crop grown in the state of Bihar, the state ranks 7th in the country in terms of annual production of banana. In Bihar state, there are two distinct banana growing areas viz. old Vaishali region and new North- Eastern (Koshi) region, both of the regions are enriched with congenial climatic conditions favourable for growth and development of banana. It is a good source of income for small as well as large farmer who produce it either on small or large level.
Recently, the demand for banana is increasing and area under the crop in the state has undergone larger expansion in the 20 years. However, banana was introduced in Kosi region during late seventies, the rate of adoption was very fast during eighties and today this belt produces nearly two-third of total banana in the state.

Thana Bihpur in Khagaria and Nauvgachhia in Bhagalpur and larger area in Katihar, Purnea and Saharsa districts have now acquired appropriate status in banana production in this Region. Remaining one-third production comes from the old banana growing belt of Vaishali and Samastipur district where tall banana cultivars are mainly grown. It is being grown commercially in the districts of Muzaffarpur, Vaishali, Samastipur and Darbhanga districts.

Banana crop is affected by a number of diseases like Panama wilt, bacterial wilt disease, Sigatoka leaf spot, bunchy top of banana and other infestation caused by many pathogens and insects. Global banana production is intensely threatened by the reemergence of a Fusarium wilt. The first description of Fusarium wilt in banana and plantains came from Australia; it was done by Bancroft (1876).

It became epidemic in Panama during 1890 and devastated almost all the banana industries of Central American and Caribbean. The causal organism of the disease is Fusarium oxysporum f. sp. cubense. So far, four races of Fusarium oxysporum f. sp. cubense (Foc) have been reported (Moore et al., 1995) based on their pathogenicity to different banana cultivars. It became epidemic in Panama during 1890 and devastated almost all the banana industries of Central American and Caribbean. In Asia, the disease was first time described in 1911 in West Bengal of India, and the disease now is widespread and 
destructive in the banana-growing states of India, causing disease incidence up to $30 \%$ in the plant crop and of $85 \%$ in the ratoon crop (Thangavelu et al., 2001). Roving survey was conducted in 61 orchards of four districts of Kerala (Palakkad, Thissur, Ernakulam and Wynad) during 2005-06 and in 50 orchards of five districts of Kerala (Calicut, Thrissur, Ernakulam, Thriuvananthapuram and Kottayam) during 2006-2007.

Panama wilt was recorded only in Rasthali $(\mathrm{AAB})$ and its incidence was very severe in districts like Wynad and Thrissur (Anon., 2008b). Survey conducted during 2008, revealed that the Fusarium wilt incidence was recorded in Ney Poovan up to 20 per cent in Erode district (Anon., 2009).

Sanjeev Kumar et al., (2010) reported that Fusarium wilt incidence was highest in Vallampadugai followed by Vadakkumangudi and Eyyalore. The other locations viz., Velacherry, Naduthittu and Arasoor recorded a moderate disease incidence (20-25\%) while the wilt incidence was low at Pudhuchathiram $(2 \%)$ in Tamil Nadu.

\section{Materials and Methods}

Extensive work on roving survey was conducted during 2016-17 to 2018-19 in different places of Samastipur, Muzaffarpur, Vaishali, Darbhanga, Bhagalpur, Katihar, Purnea, Saharsa and Kishanganj districts of Bihar. During survey observations were recorded with respect to cultivar, planting material used, number of orchards surveyed and percent wilt index based on the external symptoms. Samples were collected for isolation of pathogens and isolated pathogen sent to Agharkar Research Institute, Pune for confirmation of pathogen. In each plot random samples were made, from which disease intensity of Panama wilt of banana was recorded as per International Musa Testing
Programme (IMTP) rating in 0-5 scale and percent wilt index was calculated-

Percent wiltindex

$=\frac{\text { Total sum of numerical rating }}{\text { Total number of plant observed } x \text { maximum category in the score chart }}$

\section{Results and Discussion}

The tested fungal strain showed $100 \%$ sequence similarity with Fusarium oxysporum f.sp. cubense race 4 strain $\mathrm{B}_{2}$ of NCBI accession number LT 571434.1. The data on roving survey of Panama wilt during 2016-17 to 2018-19 in different banana production zone of Bihar viz., Samastipur, Muzaffarpur, Vaishali, Darbhanga, Katihar, Purnea, Bhagalpur, Saharsa and Kishanganj districts to assess the percent wilt index of Panama disease on different varieties of banana presented in Table 1 and Table 2.

A roving survey for the incidence of Panama wilt was undertaken in different districts of Bihar during April, July and October 2016-17 to 2018-19. The surveyed data revealed that the disease was present in all the surveyed districts. In Vaishali belt, the percent wilt index of this disease was highest (36-40\%) in cultivar Malbhog of Samastipur district followed by Vaishali district (36-38\%) and Darbhanga district (36-38\%) during 2016-17.

However, the percent wilt index of Panama wilt was lower during 2018-19 in this zone. In Koshi belt, the highest percent wilt index was found in cultivar Grand Naine (28-34\%) of Bhagalpur district followed by Katihar district (28-30\%) in cultivar Grand Naine and Kishanganj district (24-28\%) in cultivars Robusta during 2016-17. However, the percent wilt index of Panama wilt disease was higher during 2018-19 because this disease was simultaneously showed increment in all year during the work of my survey. 


\begin{tabular}{|c|c|c|c|c|c|c|c|}
\hline \multicolumn{8}{|c|}{ Table.1 Roving survey of Panama wilt of banana in Vaishali belt (Zone I) of Bihar } \\
\hline \multirow[t]{2}{*}{ Districts } & \multirow[t]{2}{*}{ Variety } & \multirow[t]{2}{*}{$\begin{array}{l}\text { Genomic } \\
\text { group }\end{array}$} & \multirow{2}{*}{$\begin{array}{l}\text { No. of } \\
\text { orchards } \\
\text { surveyed }\end{array}$} & \multirow[t]{2}{*}{$\begin{array}{l}\text { Planting } \\
\text { material }\end{array}$} & \multicolumn{3}{|c|}{$\begin{array}{c}\text { Wilt Index [\%] } \\
(0-5)\end{array}$} \\
\hline & & & & & 2016-17 & 2017-18 & 2018-19 \\
\hline \multirow[t]{4}{*}{ Samastipur } & Malbhog & $(\mathrm{AAB})$ & \multirow[t]{4}{*}{26} & Sucker & $36-40$ & 34-37 & 30-34 \\
\hline & Alpan & $(\mathrm{AAB})$ & & Sucker & $24-26$ & $22-24$ & $18-21$ \\
\hline & Champa & $(\mathrm{AAB})$ & & Sucker & $27-28$ & $24-26$ & $21-25$ \\
\hline & Kothia & $(\mathrm{ABB})$ & & Sucker & $24-30$ & $22-26$ & $20-24$ \\
\hline \multirow{6}{*}{ Muzaffarpur } & Malbhog & $(\mathrm{AAB})$ & \multirow[t]{6}{*}{28} & Sucker & $34-37$ & $33-36$ & $28-32$ \\
\hline & Alpan & $(\mathrm{AAB})$ & & Sucker & $22-26$ & $20-22$ & $16-20$ \\
\hline & Kanthali & (AAB) & & Sucker & $25-27$ & $24-26$ & $22-24$ \\
\hline & Champa & $(\mathrm{AAB})$ & & Sucker & $27-28$ & $24-27$ & $20-23$ \\
\hline & Kothia & $(\mathrm{ABB})$ & & Sucker & $25-29$ & $25-27$ & $20-24$ \\
\hline & Chinia & $(\mathrm{AAB})$ & & Sucker & $28-30$ & $26-28$ & $22-25$ \\
\hline \multirow[t]{5}{*}{ Vaishali } & Chinia & $(\mathrm{AAB})$ & \multirow[t]{5}{*}{24} & Sucker & $30-32$ & $28-30$ & $24-28$ \\
\hline & Malbhog & $(\mathrm{AAB})$ & & Sucker & $36-38$ & $34-36$ & $30-33$ \\
\hline & Alpan & $(\mathrm{AAB})$ & & Sucker & $25-27$ & $22-24$ & $16-18$ \\
\hline & ChiniChampa & $(\mathrm{AAB})$ & & Sucker & $23-26$ & $23-26$ & $22-24$ \\
\hline & Kothia & $(\mathrm{ABB})$ & & Sucker & $24-27$ & $22-24$ & $18-20$ \\
\hline \multirow[t]{4}{*}{ Darbhanga } & Chinia & $(\mathrm{AAB})$ & \multirow[t]{4}{*}{22} & Sucker & $26-29$ & $23-26$ & $22-25$ \\
\hline & Malbhog & $(\mathrm{AAB})$ & & Sucker & $36-38$ & $34-36$ & $28-32$ \\
\hline & Alpan & $(\mathrm{AAB})$ & & Sucker & $21-23$ & $20-24$ & $16-18$ \\
\hline & ChiniChampa & (AAB) & & Sucker & $25-29$ & $24-26$ & $20-23$ \\
\hline
\end{tabular}

Table.2 Roving survey of Panama wilt of banana in Kosi belt (Zone II) of Bihar

\begin{tabular}{|c|c|c|c|c|c|c|c|}
\hline \multirow[t]{2}{*}{ Districts } & \multirow[t]{2}{*}{ Variety } & \multirow{2}{*}{$\begin{array}{l}\text { Genomic } \\
\text { group }\end{array}$} & \multirow{2}{*}{$\begin{array}{l}\text { No. of } \\
\text { orchards } \\
\text { surveyed }\end{array}$} & \multirow{2}{*}{$\begin{array}{l}\text { Planting } \\
\text { material }\end{array}$} & \multicolumn{3}{|c|}{ Wilt Index [\%] (0-5) } \\
\hline & & & & & $\begin{array}{r}2016- \\
17\end{array}$ & $\begin{array}{r}2017- \\
18\end{array}$ & $\begin{array}{r}2018- \\
19\end{array}$ \\
\hline \multirow[t]{3}{*}{ Katihar } & Robusta & (AAA) & \multirow[t]{3}{*}{22} & Sucker & $22-24$ & $24-26$ & $26-28$ \\
\hline & Grand Naine & (AAA) & & Tissue culture & $22-25$ & $26-28$ & $28-30$ \\
\hline & Basrai & (AAA) & & Sucker & $11-13$ & $14-16$ & $16-18$ \\
\hline \multirow[t]{3}{*}{ Purnea } & Grand Naine & (AAA) & \multirow[t]{3}{*}{24} & Tissue culture & $20-23$ & $24-26$ & $28-30$ \\
\hline & Robusta & (AAA) & & Sucker & $18-23$ & $25-27$ & $30-32$ \\
\hline & Basrai & (AAA) & & Sucker & $12-15$ & $16-18$ & $18-20$ \\
\hline \multirow[t]{2}{*}{ Bhagalpur } & Grand Naine & (AAA) & \multirow[t]{2}{*}{25} & Tissue culture & $23-25$ & $26-30$ & $28-34$ \\
\hline & Robusta & (AAA) & & Sucker & $24-26$ & $26-28$ & $28-32$ \\
\hline \multirow[t]{3}{*}{ Saharsa } & Basrai & (AAA) & \multirow[t]{3}{*}{21} & Sucker & $10-12$ & $12-14$ & $14-18$ \\
\hline & Grand Naine & (AAA) & & Tissue culture & $18-21$ & $21-23$ & $24-28$ \\
\hline & Robusta & (AAA) & & Sucker & $22-23$ & $24-26$ & $28-30$ \\
\hline \multirow[t]{3}{*}{ Kishanganj } & Robusta & (AAA) & \multirow[t]{3}{*}{23} & Sucker & $20-23$ & $20-22$ & $24-28$ \\
\hline & Basrai & (AAA) & & Sucker & $9-11$ & $12-14$ & $14-18$ \\
\hline & Grand Naine & (AAA) & & Tissue culture & $18-21$ & $22-24$ & $24-26$ \\
\hline
\end{tabular}




\begin{tabular}{|l|l|}
\hline Category & Reaction \\
\hline $\mathbf{1}$ & Healthy \\
\hline $\mathbf{2}$ & Slight chlorosis and wilting with no petiole buckling \\
\hline $\mathbf{3}$ & Moderate chlorosis and wilting with some petiole buckling and or splitting of leaf base \\
\hline $\mathbf{4}$ & Severe chlorosis, severe wilting, petiole buckling and dwarfing of newly emerged leaf \\
\hline $\mathbf{5}$ & Dead \\
\hline
\end{tabular}

Fig.1 Roving survey of Panama wilt of banana in Vaishali belt (Zone I) of Biha
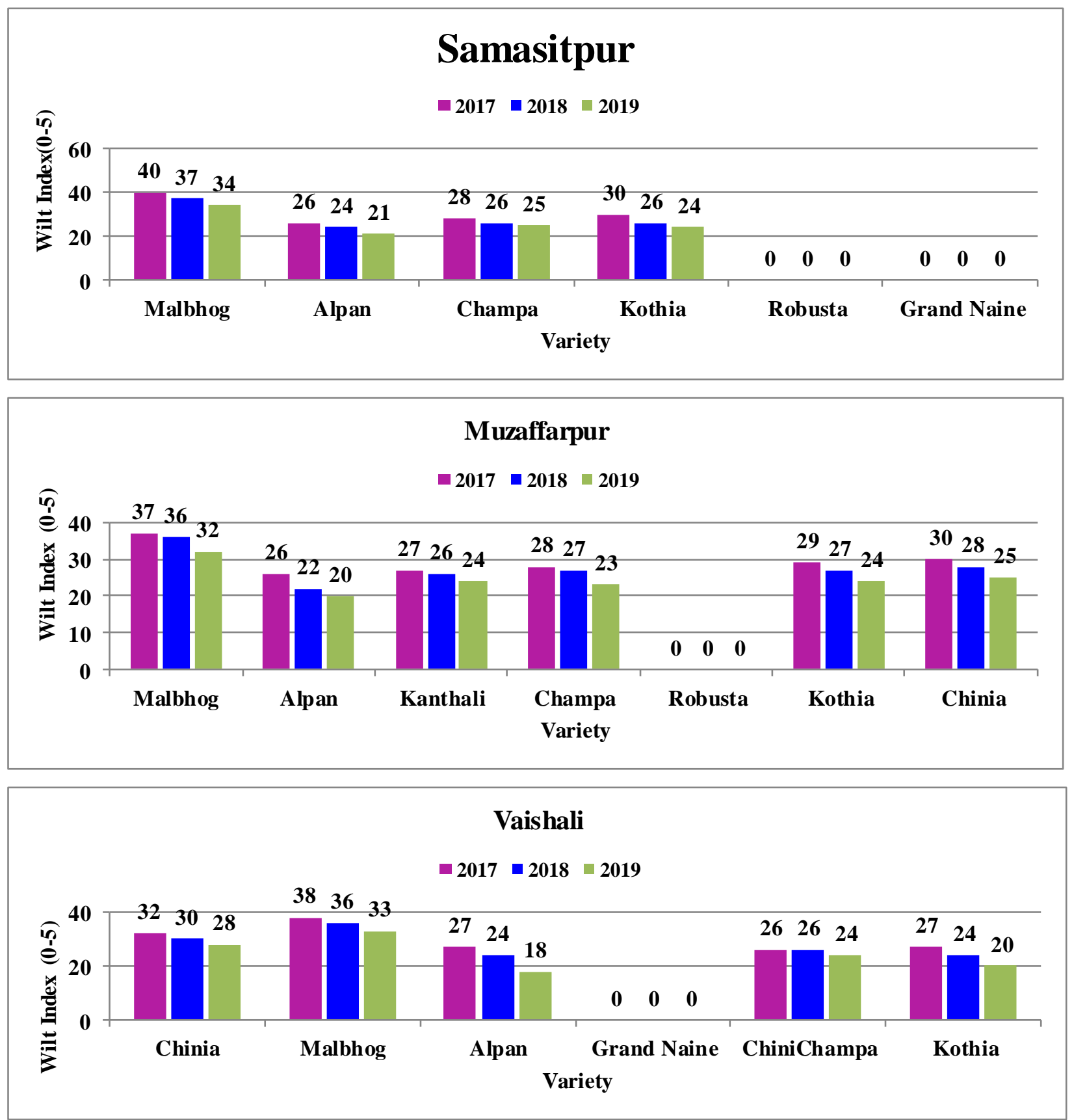


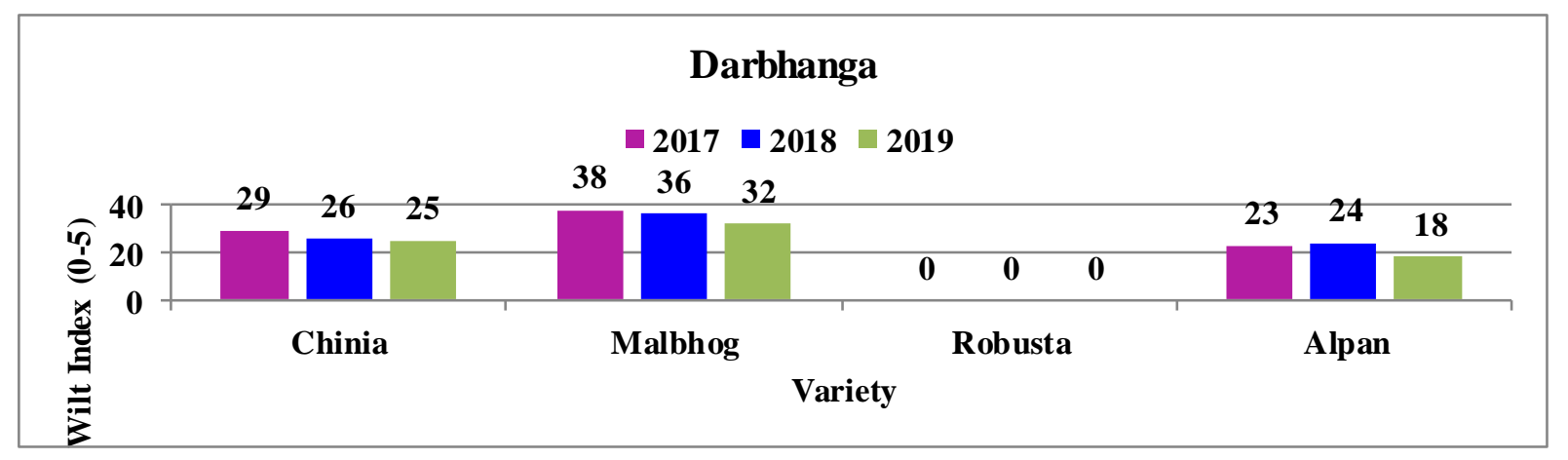

Fig.2 Roving survey of Panama wilt of banana in Koshi belt (Zone II) of Bihar
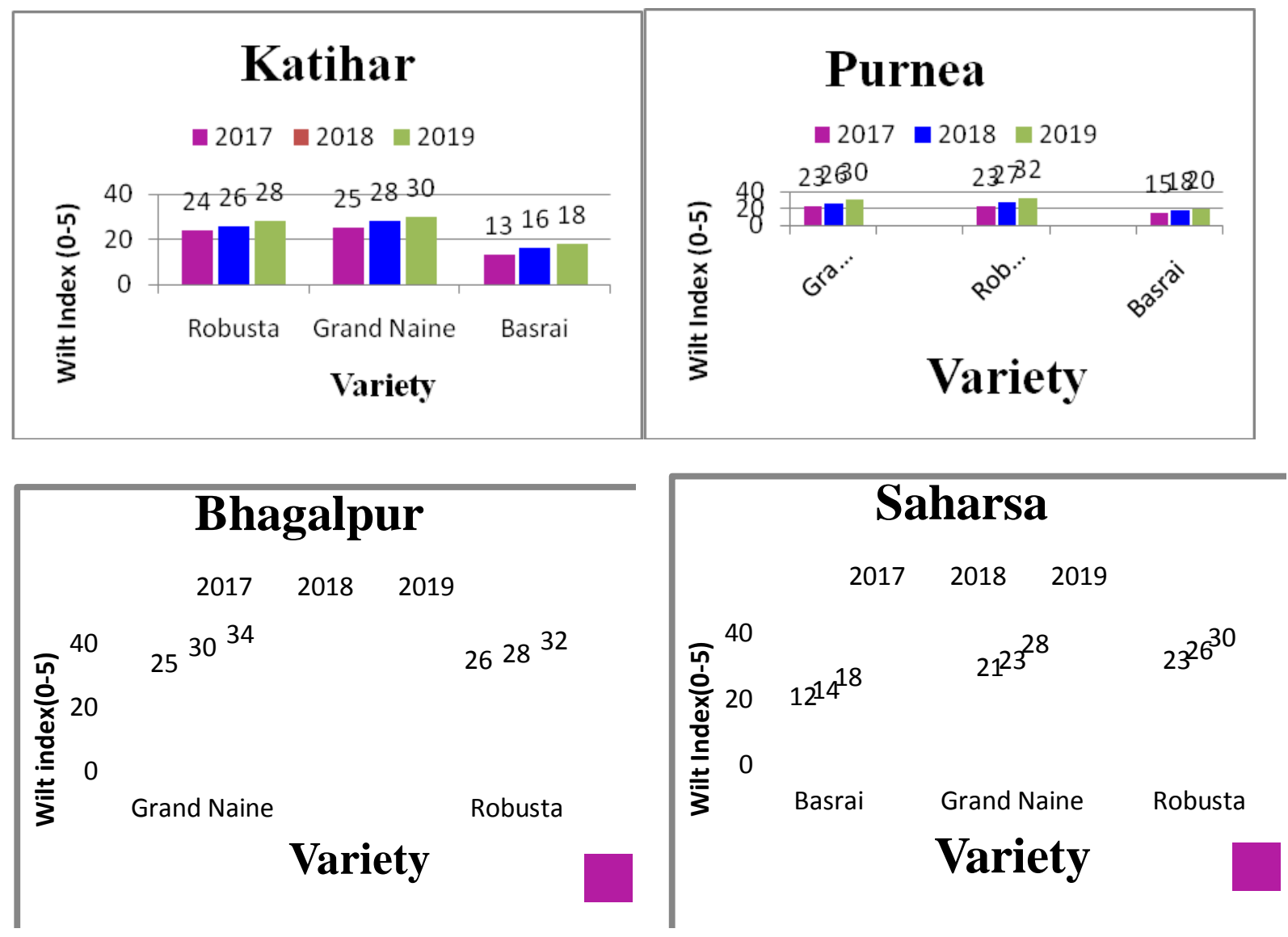

\begin{tabular}{|c|c|c|c|c|}
\hline & & Kis & anganj & \\
\hline & & 2017 & 2018 & \\
\hline 50 & 232228 & & 111418 & 212426 \\
\hline হু & Robusta & & Basrai & Grand Naine \\
\hline 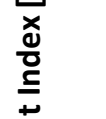 & & & Variety & \\
\hline
\end{tabular}


Fig.3 Symptom observation of Panama wilt in dwarf Cavendish group of bananas in Kosi belt of Bihar
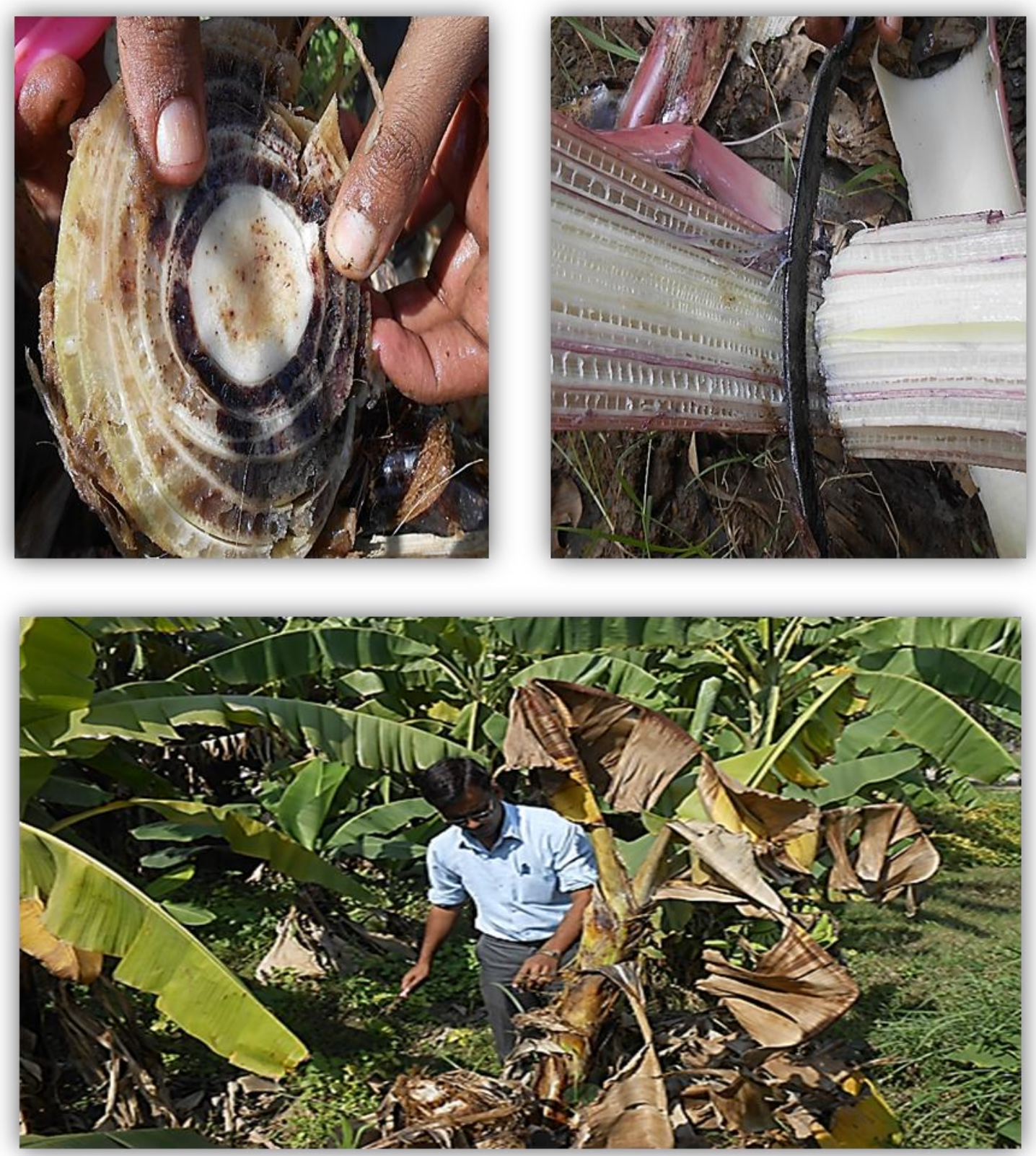

Banana cultivation in Bihar was categorised into two distinct zone one is Vaishali belt and other is Kosi belt. In Vaishali belt mostly tall group of banana cultivars were used by the banana growers where as in Kosi belt generally dwarf Cavendish group of banana cultivars were used by the farmers in larger scale. In Vaishali belt, during observation of percent wilt index of banana, showed reduction in every year in all the surveyed banana cultivars. In addition to other in Koshi belt all the banana cultivars were showed increasement in percent wilt index of panama wilt due to introduction of new pathogenic race and banana growers in this area used other crops (Potato, Maize) in place of 
banana. This highly virulent form pathogenic race was more calamitous and devastative due to absence of any effective management practices. From 1890 to 1960, about 40,000 ha of banana cv. Gros Michel were destroyed or abandoned in Latin America and Caribbean because of Fusarium wilt (Moore et al., 2001). Earlier, a virulent strain of Foc affecting Cavendish type of banana has been identified in India (Mustafa et al., 2010) and recently a highly virulent strain of Foc i.e. Tropical Race 4 has been identified which was affecting Cavendish type banana cultivar Grand Naine in Uttar Pradesh (Damodaran et al., 2018). Prasadji (2006) surveyed different regions of Andhra Pradesh and reported that the disease incidence was highest in Silk group cultivars viz., Amritapani and Rashthali grown mainly in the coastal districts of Andhra Pradesh. Considerable disease incidence was also recorded in Pisang Awak group cultivar, Karpuravalli (3-18\%) in Nellore district and cooking cultivar, KovvurBontha $(2-5 \%)$ of the Bluggoe subgroup.

In Bihar Foc race - I and race - II were already present, due to which all tall banana varieties were susceptible and at risk.Now in Bihar and at national level, Panama wilt disease became most serious threat to banana cultivation because first time we confirm the presence of TR4 strain $B_{2}$ in Bihar states of India. All the varieties of banana are susceptible to Foc race TR4.Work on management of Panama wilt of banana incited by Fusarium oxysporum f. sp. cubense tropical race 4 strain $\mathrm{B}_{2}$ is in progress.

\section{References}

Anonymous, (2008b). Biennial research report, Group discussion of All India Coordinated Research Project and ICAR AD-HOC schemes on Tropical Fruits, Tamil Nadu Agri. Univ., Coimbatore. p- 373.
Anonymous, (2009). Biennial research report, Group discussion of All India Coordinated Research Project and ICAR AD-HOC schemes on Tropical Fruits, Kerala Agri. Univ., Thrissur, pp-335370.

Bancroft, J. (1876). Report of the board appointed to enquire into the cause of disease affecting livestock and plants, Queensland. In: Votes and Proceedings, 3: 1011-1138.

Damodaran, T., Mishra, V.K., Jha, S.K. and Ram Gopal (2018). Frist report of Fusarium wilt in banana caused by Fusarium oxysporum f. sp. cubense tropical race 4 in India. Plant disease doi.org/10.1094/PDIS-07-18-1263PDN.

Horry, J.P., Arnaud, O.E., Crouch, J.H., Jones, D.R., Mateo, N., Picq, C. and Vuylsteke, D. (1997). Banana and Plantain. Chapter 6. In: D Fuccilo, L Sears, P Stalpeton, eds. Biodiversity in Trust. Conservation and Use of Plant Genetic Resources in CGIAR Centres. Cambridge University Press, Cambridge. pp: 67-81.

Mohapatra D, Mishra S, Sutar N. (2010). Banana and its by-product utilization: an overview. J Sci Ind Res. 69:323-329.

Moore N.Y, Bentley S, Pegg K.G. and Jones D.R. (1995). Fusarium wilt of banana. Musa disease fact sheet. INBAP Montpellier, France, 5:4.

Moore, N.Y., Pegg, K.G., Bentley, S.C. and Smith, L.J. (2001). Fusarium wilt of banana.Global problems and perspectives. In: Banana Fusarium Wilt Management. Towards Sustainable Cultivation. A.B. Molina, N.H. Nikmasdek, K.W. Liew (eds), INIBAP - ASPNET, Los Banos, Laguna, The Phillippines, pp: 11-31.

Mustaffa M.M., Thangavelu R (2010). First report on the occurrence of a virulent strain of Fusarium wilt pathogen (Race- 
1) infecting Cavendish (AAA) group of bananas in India. Plant Disease 94: 1379.

Prasadji K.J. (2006). Race and vegetative compatibility group of Fusarium oxysporum f. sp. cubense isolates in Andhra Pradesh. Indian Journal of Mycology and Plant Pathology, 36(2): 237-240.

Sanjeevkumar, S. K., Balabaskar, P. and Muthukumar, A., (2010). Occurrence of wilt of banana and variability in pathogen Fusarium oxysporum f. sp. cubense in Cuddalore district of Tamil Nadu, J. Mycol. Pl. Pathol., 40(3): 473475.

Thangavelu, R., Sundararaju, P., Sathiamoorthy, S., Raguchander, T.,
Velazhahan, R., Nakkeeran, S. and Palaniswami, A. (2001). Status of Fusarium wilt of banana in India. In: Molina, A. B., Nikmasdek, N. H., Liew, K. W. (Eds.), Banana Fusarium wilt management towards sustainable cultivation. INIBAP-ASPNET, Los Banos, Laguna, Philippines, pp. 58-63.

Tripathi L. (2011). Biotechnology in Musa improvement. In: Pillay M, Tenkouano A, editors. Banana breeding: progress and challenges. London: CRC press Taylor \& Francis Group; p. 219_236.

Wall M.M. (2006). Ascorbic acid, vitamin A, and mineral composition of banana (Musa sp.) and papaya (Carica papaya) cultivars grown in Hawaii. Journal of Food Composition Annal. 19:434_445.

\section{How to cite this article:}

Shukla, D.N. and Singh, S.K. 2019. An Extensive Work on Roving Survey of Panama wilt Disease (Fusarium oxysporum f. sp. cubense) of Banana in Bihar. Int.J.Curr.Microbiol.App.Sci. 8(07): 1809-1817. doi: https://doi.org/10.20546/ijcmas.2019.807.215 